\title{
Flags, Anthems, and the Politics of Free Speech in a Trump White House
}

\author{
Daniel Broudy
}

\section{Introduction}

Humans are curious creatures, capable of incredible compassion and yet able to concoct every intrigue and corruption imaginable. We take no responsibility for the diseases, disorders, poverty, or famine that befall our kind. We build religions to imagined communities and symbols of our own temporal power needed (we feel) to focus the attention of our fellow men and women on what is really important. We call it nationalism, dressed in signs and symbols that beckon us all to bow before their forms.

But if nationalism, as Franz Werfel once observed, is a "heretical religion based on the erroneous doctrine that nations have a soul and that this soul is more permanent, more 'eternal,' so to speak, than the soul of an individual" (1944), this claim raises a question. Can Werfel's words speak to us in the present? Representing the sentiments of a writer and advocate for nonviolence and love for all humankind, his observation might help explain the contemporary condition of public and free speech and the possible ramifications for desecrating symbols of the national soul, so to speak. While he wrote before and during Nazi aggression in the reign of the Third Reich, Werfel's insight might shed light on our present attempts to understand the dangers unfolding before us.

This essay is an effort to assess a particular strain of nationalism appearing in the Administration of Donald J. Trump. It critically examines how the President manages to appeal to the mass of his fervent followers, to disseminate and enforce his idiosyncratic concept of citizenship while working to veil from wider view an underlying plan which, by many signs, appears to be a more empowered plutocracy. Trump's present aim, it appears, seeks to bring to full bloom the seeds of a nationalism sown in the presidency of George H. W. Bush that can be seen in the fruits of a pliable and obedient American people less and less likely to exercise their free speech rights and speak out against state abuses of power for fear of economic marginalization and/or ruin at the hands of ruling and all-knowing wealth.

Standing before an imposing backdrop of American flags and referring to China and Russia as "rival powers," Trump notes in remarks on his National Security Strategy that these nations, "seek to challenge American influence, values, [and] wealth" (2017), which he said were increasing under his administration. Besides his purported personal insecurities (small hands, male pattern baldness, questionable IQ, etc. [Bookman 2018]) and obsession with trivialities (small inauguration attendance), Trump's concept of American values seems to be little more than the possession and expression of material wealth and market performance, which (for him) creates self-justified influence. "America is gaining wealth, leading to enhanced power-faster than anyone thought—with $\$ 6$ trillion more in the stock market alone since the election-\$6 trillion," he observed (2017).

The smooth operation of business and meeting the bottom line is necessarily the exclusive metric by which market value and, hence, citizen value is measured. Trump's nationalism is woven into his unique interpretation of and value in personal and national economic power. His interpretation of value, wealth and influence, like his predecessors', are symbolized, it seems, in the massive American flag that decorates the entrance of the New York Stock Exchange. To military men and women, however, called upon (by successive administrations) to sacrifice their bodies or minds for that symbol, the national flag engenders starkly different conceptual imagery—a patch on the 
shoulder of a comrade in combat, a flag-draped coffin, the spangled banner hoisted or lowered on a flagpole during morning or evening colors.

\section{Keywords}

Since nationalism and patriotism are sometimes conflated and/or confused, it is important to clarify their distinctions. I begin with the peculiarities parsed by journalist Sydney J. Harris:

The difference between patriotism and nationalism is that the patriot is proud of his country for what it does, and the nationalist is proud of his country no matter what it does; the first attitude creates a feeling of responsibility, but the second a feeling of blind arrogance that leads to war. (1953)

Blind arrogance and the complete absence of responsibility toward others are key features in today's nationalist. The loudest and most vulgar cheering sections in the public discourse conditioning the public mind to receive particularly virulent strains of nationalism wrap themselves in the colors of the flag (or display the colors prominently on their jacket lapel during network broadcasts).

When Sean Hannity, for example, commentator and seasoned cheerleader for preemptive military invasions and regime changes throughout the world, reminds interviewees appearing on camera and explaining the militaryindustrial perspective that they are "Great Americans," his exuberance can be best understood in the nationalist light shone by Harris. In April 2017, after Trump launched a Tomahawk missile into Syria, Hannity noted that Trump's message to the world could not be any clearer: "The United States of America is back" —as if somehow to pretend that America had previously abandoned its foreign policy of actively seeking regime changes throughout the world. Here, Hannity, as a powerful talking head, shirks his immense responsibility to call critical attention to the larger national responsibility that bombing has on the people-both within the United States and, importantly, beyond its borders. Hannity further observes in his television broadcast that:

Syria, North Korea, Iran, Russia, China and the rest of the entire world saw a very different United States of America last night. Instead of weakness, we now have strength. Instead of appeasement [and] capitulation, we now have decisiveness and leadership. Timidity has been replaced by bold action. (2017) [1]

If, in surveying the world, the nationalist insists on seeing only in black-and-white terms, the patriot sees and appreciates the diversity in the colors of its people. "A patriot is necessarily and invariably a lover of the people" (1774), notes famous lexicographer and patriot, Samuel Johnson. He further observes that, "A patriot is he whose public conduct is regulated by one single motive, the love of his country; who, as an agent in [government], has, for himself, neither hope nor fear, neither kindness nor resentment, but refers everything to the common interest" (1774). Though addressing the electors of Great Britain at the time, Johnson speaks in a meaningful way to America's pretenders today: the common good, rather than corporate personhood, must be served by those in power who claim to love the fatherland.

\section{Normalizing Belligerence}

One important aspect of the particular brand of nationalism that Trump trades in began appearing during the George H. W. Bush presidency, continued through his son's (W's) administration, and with greater frequency through the Barack Obama presidency. With the impending 1991 Gulf War, President Bush observed in his address to the nation that the United States can [with belligerence] forge for Americans and future generations a new world order, a world where the rule of law, not the rule of the jungle, governs the conduct of nations (Bush, 1991). Speaking for the American people, Bush summoned the sacred mythologies of nationhood by citing the rule of law while, at the same time, enacting rules of the jungle to war against another country that had subsumed a neighboring nation.

This new world order of which President Bush spoke has sought to make the nation the exclusive center of man's creation. This reinterpretation of the concept of the ancient social order has remade God into a servant of the nation rather than the nation into a servant of God's purpose for man. Michael Billig notes that, "If there is an 
ideological aura attached to nationhood, then the role of God in this down-to-earth ... mysticism is interesting" (1995). The fascination can be found in the stark differences that appear in how the prospect of war (or the necessity of perpetual conflict) is pitched to populations across cultures. As Saddam Hussein invoked the rhetoric of an era preceding the modern nation-state fighting against "the army of atheism," Bush invited God merely to make a rhetorical appearance, calling on His name to "bless our forces" and the "coalition forces at our side" (Billig, 1995). Each belligerent action undertaken throughout the world by subsequent US administrations has called upon God to serve in this new conceptualization of the order of nations.

Infused in man's call for God to serve man's aims is the unspoken effort undertaken in mass media to make preemptive forms of belligerence normal. This process of normalization has enlisted the nation's most significant symbol, the flag, to play the crucial role of blotting out from public view the underlying system of military aggression that, "doesn't do body counts" (Franks, 2002) for foreign casualties on foreign soil. In the wake of the Gulf War, the post-9/11 world reveals, also, a form of nationalism in America arrogating to itself the power to dissolve popular sovereignty and basic citizen rights under the banner of the flag and its purported sanctity. This is the sort of belligerence that Representative Tulsi Gabbard (Army combat veteran) referenced in an interview with ABC's George Stephanopoulos (January 2018). In responding to his question about a ballistic missile attack from North Korea, which turned out to be a false alarm, Gabbard observes that,

... our country's history of regime-change wars [has] lead countries like North Korea to develop and hold on to nuclear weapons because they see how the United States, in Libya for example, guaranteed Gaddafi, we're not going to go after you; you should get rid of your nuclear weapons. He did, [but] then we went and led an attack that toppled Gaddafi, launching Libya into chaos that we are still seeing the results of today. (2018)

At the very center of the conditioning process that hides this history with one hand and normalizes belligerence with the other are the flag and anthem. The conditioning can be seen in the concrete public veneration of symbols: the field-sized flags unfurled (with taxpayer money) for the national anthem on game day (Fenno \& Zarembo, 2015), the orchestrated public exhibitions of homecoming affection for veterans keen to surprise family, and the men and women arrayed in uniform (Howard, 2015) who throw (or catch) the first pitch (Kindelan, 2017), flip a coin for kickoff (NFL, 2016), or drop the puck on center ice (Sportsnet, 2016). These rituals and "gimmicks" (Lurie, 2015) of sport are in league with the state and its efforts to conflate the commonplace connotations of its symbols with mindless leisure and to elevate the nation to the heights of the sacred. Puzzled spectators, especially outside the United States, may wonder how so many American citizens have slipped into this state of nationalism even as the civil rights of so many of its citizens are shattered by the increasingly militarized state itself. A brief return to modern history should help bring some clarity to the present.

Since nationalism (cast as religion) is part of the smooth business of war (ICIJ, 2012) and maintaining the global spread of garrisons and armaments, images of the flag have increasingly been used by domestic corporate news to condition the public, reinforce the status quo, and fortify the flagging integrity of highly filtered and "distorted views of war" (Greenslade, 2010) produced by embedded journalists covering battlefield actions. War "waged from bombers [and drones] high above the fray and reported by carefully controlled journalists [has] made war fashionable," notes Chris Hedges (2010). Such synergy among corporate news mythmakers and storytellers (happy to serve as vessels of the narrative) and the agents of military action is hardly a new phenomenon as General Smedley D. Butler (recipient of two medals of honor) once noted, retired from the "racket" ([1935] 1974) he had served with high distinction.

Adam Parfrey observes in the introduction to War is a Racket (2003 Reprint edition), that Butler was arrested after he publicly spoke about Italian Prime Minister Benito Mussolini's utter callousness for the loss of one life in the affairs of the state. Only after hostile public outcry from the American people was Butler spared from courts marshal. "Pre-World War II worship of Italian Fascism in America," Parfrey writes, "can be seen in the July 1934 issue of Fortune magazine, which celebrated the Italian corporatist state" (2003). Butler, who audaciously referred to himself as a "racketeer for capitalism" (2003), infuriated the greedy capitalist class and their political lapdogs in Washington when he publicly named the names: I helped make Mexico ... safe for American oil interests ... Haiti and Cuba a decent place for the National City Bank boys. I
helped in the raping of half a dozen Central American republics for the benefits of Wall Street.... I helped purify Nicaragua
for the international banking house of Brown Brothers. I brought light to the Dominican Republic for American sugar
interests ... [and] in China I helped to see it that Stand Oil went its way unmolested. (2003:10)

Butler's confession of the movement of the nation's flag to foreign battles waged for American industry and 
banking interests reveals the brutalities necessary for the rapid spread of capitalism ignored by corporate media and obscured by the emotive powers conjured up by effective advertising of the national flag. Nor can it be a coincidence, as Woodrow Wilson once declared, that the flag of the country follows the designs of financiers and manufacturers across the world where the "doors of unwilling nations are battered down" (Cited in Chomsky, 1987) in the interest of expanding markets. What is necessary, however, is a propaganda system that effectively camouflages these colonizing activities at work in our social relations and in our minds.

\section{Conditioning and Resistance}

The widely recognized father of modern public relations, Edward Bernays observed that, "propaganda is the executive arm of the invisible government" ([1928] 2005). If such is the case, the presence and influence of propaganda is, today, much more visible in the mass media. Before America's first military foray into Iraq in 1990 and the emergence of the 24-hour news cycle, corporate media at least attempted to maintain the pretense that journalism was an independent entity from the state, a cantankerous check on the abuses carried out by state power. Today, however, scarcely any report of (inter)national import is delivered free from digital reproductions of the national flag suffused explicitly (or subliminally) with set backdrops or screen overlays as studio newsreaders follow their teleprompters (Barrón-López, 2007). The great profusion and unremitting observance of national symbols over decades engender suspicion that the state is in the business of normalizing and intensifying not just mindless mass consumption and use of products and weapons (in the name of the national interest) but a kind of idolatry as well.

In his early 20th century work Public Opinion, Walter Lippmann offers a description relevant to our 21st century problem. Of symbols and their centrality to the formation of the mass public's perceptions, thoughts, and habits, Lippmann suggested that, "no successful leader has ever been too busy to cultivate the symbols which organize his following" ([1922] 1997). George W. Bush's successful and well-known campaign to cultivate the "sacred" connotations of the American flag distilled in the lapel pin, just in the wake of 9/11 (Cruz, 2008), served in large measure to organize a mass following for the eventual preemptive invasion of Iraq and, in the midst of national hysteria and turmoil, the severe weakening of civil liberties under the USA PATRIOT Act (Sadeghi, 2003).

To be a bona fide patriot—as the Bush mythology unfolded—one had to become a nationalist and embrace, without thoughtful reflection, the new definitions of patriotism the Administration re-engineered, promoted, and controlled through compliant corporate media. Public officials who "decided [they] won't wear that pin on [their] chest" (Zeleny, 2007), obeying the new trend and signifying their obedience, became an open target for ridicule and reproach in the acquiescent media (Wright and Miller, 2007).

"The leader knows by experience," observed Lippmann, "that only when the symbol has done its work is there a handle by which he can move a crowd" ([1922] 1997). That handle, at present, is being remolded from the Trump brand name, cast in gold lettering, into the American flag and anthem. Having won the campaign for the nation's highest office, Donald J. Trump (Chief Executive of The Trump Organization) appears to be set in the business, as Commander in Chief, of cultivating his following with a campaign of rebranding. The Trump family name in plaited gold, branded on its various business edifices, signifies exclusivity and power. The brand is nothing, if not a signifier of lavish wealth. Associated conceptual images of that brand are now merging with the national flag-synthesizing commonplace concepts of patriotism and the flag and anthem to produce a brand of nationalism whose meaning and value are increasingly controlled and disseminated by elites.

In defense of President Trump's awkward comments to the father of a fallen soldier in Afghanistan, White House Chief of Staff John Kelly (ret. General) reflected on the widespread criticism of his boss and went for a contemplative "walk among the finest men and women on this earth. ... in Arlington National Cemetery." He describes in a White House press conference (October 19, 2017) how a fallen soldier is cared for: We "wrap them up in whatever passes as a shroud ... pack them in ice ... meticulously dress them in their uniform with the medals they've earned, the emblems of their service" (Kelly, 2017). Here, the symbolic imagery of a sacred "shroud" and bravery, signified in earned medals in the name of state military actions, are fused with emotive images engendered by acts of being put on ice and preserved for as long as possible. The American fighting man and woman who have made the ultimate sacrifice represent in Kelly's mind, "the best one per cent this country produces" (2017). As citizens, we either buy into these new meanings of patriotism or risk being publicly shunned and shamed by the Administration for asking critical questions (Gessen, 2017). 
Kelly, further, inserts the normalizing language of autocratic rule, "there is nothing in our country anymore that seems to suggest that selfless service is not appropriate but required," to bolster and control the Trumpian interpretation of patriotism. Reinforcing the emotions we are adjured to feel about a "military procedural on burial traditions" (Holcomb, 2009), Kelly highly recommends the public viewing of an emotive integration of Hollywood drama and actual events in the film Taking Chance. The movie is an adaptation of Lieutenant Colonel Michael Strobl's notebooks chronicling his observations and sense of guilt for working a desk job in garrison at Quantico while his comrades toiled in combat during the 2003 Iraq War. The story seeks to engender patriotic feelings of pride with conspicuous appearances of respectful salutes to service members and flags.

Though an honorable salute to a fallen Marine, the film "never rises above empty sentimentalism" to engage "with the controversial politics of the Iraq War" (Holcomb, 2009). To embrace this nationalist invention of patriotism in the worship of soulless signs and symbols and to respect the demands of elites who seek this sort of compliance means to utterly ignore the crisis on the streets of our nation - the ongoing sacrifices of veterans who with missing limbs, mangled bodies and broken hearts and minds plagued by battlefield traumas fall by their own hands in record numbers of suicides (Department of Veterans Affairs, 2016).

In Donald Trump's vision of America made great again with borders safeguarded from powerless would-be immigrants from “shit-hole' nations" (Bump, 2018), unquestioning observance of the rites and rituals of state symbol worship also means you can play the game of life (or maintain your livelihood) without being singled out for harassment by the elite owners of wealth or by the leading players in entertainment or material production. Exercising the right to speak out can be seen, also, in the resistance of inaction, or nonparticipation. A growing number of professional athletes seeking to call widespread attention to ongoing social injustices and civil rights abuses (Chaney and Robertson, 2013) are refusing to stand during the playing of the national anthem, and some are paying the price, so to speak, for their disobedience.

Taking a knee today during the playing of the national anthem is yesterday's sit-in at places of public accommodation where institutionalized expressions of racism sought to remold Americans of African descent into second-class citizens. The symbol of a unified nation for Trump has become a symbol of "jangling discord" (King 1963) for citizens who plainly see, with each new day, the reemergence of systemic oppression and violence but refuse to remain quiet about it. In commenting on continuing NFL player protests against police brutality in communities across the United States, Trump ignores these realities and, instead, fires up his base:

Wouldn't you love to see one of these NFL owners, when somebody disrespects our flag, to say, 'Get that son of a bitch off the field right now. Out! He's fired. He’s fired! (Graham, 2017)

To Trump, blind obedience to the present norm appears to equate to continued access to and participation in civil economic life. Dealing squarely with facts about the excesses of policing power, "the violated civil rights and endangered lives" (Chaney and Robertson, (2013,494), is far less valuable than maintaining control over the nationalist narrative and moving the masses in the direction of full compliance.

Control over society's key definitions is, in fact, integral to the process through which power is able to dictate not only what is and isn't factual, but what is and isn't valuable (Schiller, 1999). A glance at the change of new décor, carpets, curtains, and couches (Seipe, 2017) in the Oval Office will apprise the casual observer that traditional signifiers of state power (red, white, and blue) are now being saturated by images of Trumpian gold. A reciprocal effect can be found in other signifiers of convergence in the various meanings engendered by both the Trump name and by State power, which have appeared in Trump flags flown on US military vehicles (Holley, 2017).

"In the symbol," Lippmann pointed out, "emotion is discharged at a common target, and the idiosyncrasy of real ideas blotted out" ([1922] 1997). With the degradation of political discourse where real and diverse ideas are exchanged with order and decorum in civil debate, Trump's ongoing belligerence campaign (Editorial, 2017) is slowly degrading the idiosyncrasies of critical thought once brought into the public square for refinement. The discharge of emotion, "knock the crap out of them," (White 2016) at campaign rallies, featuring Trump's rhetorical brand, vividly illustrated the extent to which passions rose to blot out rational discourse only to be replaced by rage discharged at convenient scapegoats_ "Mexicans" (Desmond-Harris, 2016), "Muslims" (Al Jazeera. 2017), "dreamers," (Nakamura, 2017) and women" (Vagianos, 2017).

"Nobody should be allowed to burn the American flag-if they do, there must be consequences-perhaps loss of citizenship or a year in jail!" Donald Trump observed (2016). Wherever objects of passionate rage are found enduring the slings and arrows of outrageous hatred, the wo/men in power aiming at those targets can also be 
found arrogating to themselves passionate praise for their efforts in further marginalizing the weak. As a fair-haired business mogul, Trump effectively defined the fringe elements during his presidential campaign, and now works as the national leader to condition the larger public to the new reality that "dissent" (Smith et al., 2017) will not be tolerated.

Since flag burning is often seen as the supreme speech act of protest (apart from self-immolation), Trump is attempting to set the tone for future actions that might well be taken against anyone bold enough to exercise free speech and disobey. Observers may have wondered whether his words are Hollywood bluster or cool sincerity, but he appears determined (one way or another) to organize a larger and larger cult following. Compliance with the President's narrow views on free speech may be coupled, for example, with a social and monetary cost. His Department of Justice head has recently demanded, "the private account information of potentially thousands of Facebook users in three separate search warrants ... to anti-administration activists who have spoken out at organized events" (Schneider, 2017). A Trump invasion of the largest online social network has the hallmarks of a campaign aimed at control not just over the public discourse, but also discourse across cyberspace. With his "repeal of online privacy protections" (Reilley, 2017) and "elimination of net neutrality" (Shamsian, 2017), Trump is well positioned, through the revolving-door of corporatists in his cabinet, to make speech and equal access to mass communication a veryexpensive prospect, indeed.

\section{Conclusion}

President Trump's previous musings about the possible consequences for disobedience added to his expressed contempt for the First Amendment (Toobin, 2016) appears to illustrate an aim toward autocratic control that would strive to blot out from public view judicial decisions already well-grounded in previous Supreme Court rulings on flag burning as a speech act protected by the Constitution (Bomboy, 2015). Having (reportedly) dodged (Evans, 2016) his "patriotic" duty to defend the flag and freedom on a battlefield in Vietnam and having since berated those who have (and have been captured doing so) (Martin and Rappeport, 2015), it is important to contemplate why Mr. Trump might now be attending so carefully to the protection of this symbol.

As state symbols are concrete expressions of national pride and identity, they sit at the center of a nation's selfperception and serve simultaneously as representations of the elect. Desecration (or even disrespect) of symbols can be construed as an existential attack on the leader. Whereas enthroned monarchs receive adulation through their jewel encrusted crowns and scepters, state leaders taking seats of power through election receive their adulation through the public's respect for the nation's symbols. If what Lippmann suggests is true, in part or whole, the leader as head of state enjoys worship vicariously.

The elect, perceiving themselves as truly set apart, receive a kind of public veneration. In the case of Mr. Trump, this level of holiness necessitates vigilant reinforcement, in his mind evidently, in a "National Day of Patriotic Devotion" (McGill 2017) as well as in a "Day of Loyalty" with the public recitation of the Pledge of Allegiance in a nation purported to be "the world's leader in upholding the ideals of freedom, equality, and justice" (Fox News, 2017). This public worship trades not only on the power of the one elected but fortifies at the same time the authority of the leader and the national symbol by fusing the two in the public consciousness. Thus, by decree and cultural conditioning aided by compliant media, the elect set the definitions of who and what are holy, or acceptable, as well as who and what are aberrant and disposable. With open access to mass media, the elect shape the meanings of core concepts and disseminate them for mass consumption.

In the business world, no one questions the boss. If you do, you risk being fired. The boss holds power to define what is and isn't true. In this era of fake news when ontological realities are remolded with false urgencies manufactured by political and corporate power, citizens must now ask whether Trump sees the people as little more than cast members in this simulacrum of central government. For fourteen seasons, The Apprentice reality show taught Donald Trump to view its audience and contestants as a class of candidates vying for something "real." In this age of the political hyper-real, where the public struggles to discern what is and isn't true, is Trump simply playing the public for higher ratings? Or, is the populist bombast and appeal actually meant to be something genuine? Either way, the prospects for a future of free speech seem bleak, save for fearless, vigorous, and sustained public campaigns that openly question all of today's elite mythmakers. 


\section{Acknowledgments}

A special thanks to Dr. Matthew Alford and Dr. Jeffery Klaehn for their constructive comments on earlier drafts.

\section{Endnotes}

1. Worth noting are important parallel actions ignored by chicken-hawk commentators in corporate news: the blistering speed with which hasty praise is heaped upon leaders who launch swift missile strikes and the speed with which the value of stocks in weapons manufacturing spike. In Investor's Business Daily, Nancy Gondo and Gillian Rich refer in their article "Syria Attacks Light
Up Dow Stock, Defense Names," to the value of each Tomahawk missile and the weapons industry's main players whose stocks "lit up" after the strike. (April 7, 2017).

\section{References}

Al Jazeera. 2017. http://www.aljazeera.com/news/2017/09/ trump-slaps-travel-restrictions-korea-venezuela-17092501 2654413.html. Accessed October 24, 2017.

Barrón-López, Laura and Travis Waldron. 2007. "Pentagon Paid Up To \$6.8 Million Of Taxpayer Money To Pro Sports Teams For Military Tributes." https://www.huffingtonpost. com/entry/defense-military-tributes-professional-sports_ us_5639a04ce4b0411d306eda5e. Accessed October 26, 2017.

Bernays, Edward. [1928] 2005. Propaganda. New York: Ig Publishing.

Billig, Michael. 1995. Banal Nationalism. London: Sage.

Bomboy, Scott. 2015. "Inside the Supreme Court's flag burning decision." https://constitutioncenter.org/blog/inside-thesupreme-courts-flag-burning-decision. Accessed October 1, 2017.

Bookman, Jay. 2018. "A Parade of Trump's Insecurities," Atlantic Journal Constitution.” https://www.myajc.co $\mathrm{m} / \mathrm{news} /$ opinion/opinion-parade-trump-insecurities/ HuL1KKxPk7ck8FrT90zlJN/. Accessed July 18, 2018.

Bump, Phillip. 2018. "Most Americans considered Trump's 'shithole' comments racist." Washington Post. https://www. washingtonpost.com/news/politics/wp/2018/01/17/mostamericans-saw-trumps-shithole-comments-as-racist/?utm_ term $=.8591 \mathrm{f1c92ec3}$. Accessed January 17, 2018

Bush, George H. W. 1991. "Address to the nation announcing allied military action in the Persian Gulf." The American Presidency Project. http://www.presidency.ucsb.edu/ ws/?pid=19222 Accessed January 10, 2018.
Butler, Smedley D. [1935] 1974. War is a Racket. New York: The Revisionist Press.

Chaney, C. \& Robertson, R.V. 2013. "Racism and Police Brutality in America." Journal of African American Studies 17: 480. https://doi.org/10.1007/s12111-013-9246-5

Chomsky, Noam. 1987. On Power and Ideology: The Managua Lectures. Boston: South End Press.

Cruz, Gilbert. 2008. "A brief history of the flag lapel pin." http:// content.time.com/time/nation/article/0,8599,1820023,00. html. Accessed October 24, 2017

Department of Veterans Affairs. 2016. "Suicide among veterans and other Americans: 2001-2014." Office of Suicide Prevention. https://www.mentalhealth.va. gov/ docs/2016suicidedatareport.pdf. Accessed January 17, 2018.

Desmond-Harris, Jenée. 2016. "All the black and brown people have to leave." https://www.vox.com/ identities/2016/10/20/13319366/donald-trump-racismbigotry- children-bullying-muslim-mexican-black-immigrant. Accessed October 4, 2017.

Editorial. (2017). "The Guardian view on Trump at the UN: bluster and belligerence." https://www.theguardian.com/ commentisfree/2017/sep/19/the-guardian-view-on-trump-atthe-un-bluster-and-belligerence. Accessed October 24, 2017.

Evans, Anne. 2016. "Donald Trump, draft dodger: Why it matters." http://theresurgent.com/donald-trump-draftdodger-why-it-matters/. Accessed September 11, 2017. 
Fenno, Nathan and Alan Zarembo. 2015. "Deals between NFL cause a stir." http://www.latimes.com/sports/nfl/la-sp-nflmilitary-20150512-story.html. Accessed October 26, 2017.

Fox News. 2017. "Trump proclaims May 1 as 'Loyalty Day'” http://www.foxnews.com/politics/2017/04/28/trumpproclaims-may-1-as-loyalty-day.html. Accessed September 11, 2017.

Gessen, Masha. 2017. "John Kelly and the language of the military coup." https://www.newyorker.com/news/news-desk/johnkelly-and-the-language-of-the-military-coup. Accessed October 24, 2017.

Graham, Bryan A. 2017. "Donald Trump blasts NFL anthem protesters: 'Get that son of a bitch off the field'” https//www. theguardian.com/sport/2017/sep/22/ donald-trump-nfnational-anthem-protests . Accessed October 24, 2017

Greenslade, Roy. 2010. "How embedded journalism distorts our view of war." https://www.theguardian.com/media/ greenslade/2010/nov/23/war-reporting-theindependent. Accessed October 1, 2017.

Hannity, Sean. 2017. "Instead of weakness, we now have strength." Fox News Insider. http://insider.foxnews.com/2017/04/07/ sean-hannity-monologue-syria-airstrikes-president-trumpmessage-world ?page $=3 \& \mathrm{fb} \_$comment_id $=136424124032357$ 1_1364284686985893. Accessed March 12, 2017.

Harris, Sydney J. 1953. Strictly Personal. Washington: H. Regnery Co.

Hassan, Ran. R., Melissa J. Ferguson, Daniella Shidlovski, and Tamar Gross. "Subliminal exposure to national flags affects political thought and behavior." Proceedings of the National Academy of Sciences of the United States of America. 1975719761, doi: 10.1073/pnas.0704679104

Hedges, Chris. 2010. "War is a force that gives us meaning," in Approaches to Peace: A Reader in Peace Studies . Ed. David P. Barash. Oxford: Oxford University Press.

Holcomb, Brian. 2009. Review "Taking chance." https://www. slantmagazine.com/tv/review/taking-chance. Accessed October 4, 2017.

Holley, Peter. 2017. "A special warfare unit was spotted flying a Trump flag in public. Now the Navy is investigating." https:// www.washingtonpost.com/news/checkpoint/wp/2017/02/03/ a-special-warfare-unit-was-spotted-flying-a-trump-flagin-public-now-the-navy-is-investigating/?utm_term $=$. b4f5f7988956. Accessed October 24, 2017.

Howard, Marcus. 2015. "Pentagon spends millions paying pro sports teams to honor soldiers at games." http://www.latimes. $\mathrm{com} /$ nation/la-na-pentagon-soldiers-pro-games-20151104story.html. Accessed October 26, 2017.

ICIJ International Consortium of Investigative Journalists. 2012. "Key findings." https://www.icij.org/investigations/ makingkilling/about-project/. Accessed October 1, 2017.
Johnson, Samuel. 1913. The Works of Samuel Johnson v.14 pp. 81-93. Troy, NY: Pafraets \& Company. http://www. samueljohnson.com/thepatriot.html. Accessed January 17, 2018.

Kelly, John. 2017. "White House Chief of Staff on President Trump's phone call to family of fallen soldier (C-SPAN)." https://www.youtube.com/watch?v=sWq26lBlMo . Accessed October 24, 2017.

Kindelan, Katie. 2017. "Military dad poses as catcher at baseball game for emotional surprise for kids." http://abcnews. go.com/Lifestyle/military-dad-poses-catcher-baseball-gameemotional-surprise/story? id=47129107. Accessed October 26, 2017.

King Jr., Martin Luther. 1963. Speech. "I have a dream." https:// www.archives.gov/ files/press/exhibits/dream-speech.pdf. Accessed January 10, 2018.

Lippmann, Walter. [1922] 1997. Public Opinion. New York: Free Press.

Lurie, Julia. 2015. "Parachute Drops, Cheerleaders, and Giant Flags: How the Pentagon Paid Pro Sports for PR." http:// www.motherjones.com/politics/2015/11/ sports-pentagonpaid-patriotism-mccain-flake/ . Accessed September 11, 2017.

Martin, Jonathan and Alan Rappeport. 2015. "Donald Trump says John McCain is no war hero, setting off another storm." https://www.nytimes.com/2015/07/17/us/ politics/trumpbelittles-mccains-war-record.html. Accessed September 11, 2017.

McGill, Andrew. 2017. "What Does Trump's 'Day of Patriotic Devotion’ Really Mean?” http://www.theatlanic.com/ politics/archive/2017/01/what-does-trumps-day-of-patrioticdevotion-really-mean/514196/. Accessed September 11, 2017.

Nakamura, David. 2017. "Trump administration announces end of immigration protection program for 'dreamers." https://www.washingtonpost.com/news/post-politics/ $\mathrm{wp} / 2017 / 09 / 05 /$ trump-administration-announces -endof-immigration-protection-program-for-dreamers/?utm term $=.0426 \mathrm{~d} 7$ f22241. Accessed October 24, 2017.

Parfrey, Adam. 2003. "How a military hero blew the whistle on corporate malfeasance." Introduction in War is a Racket. Port Townsend, WA: Feral House.

Reilly, Katie. 2017. "President Trump sign bill overturning internet privacy protections." Time. http://time. com/4724128/donald-trump-internet-history-isp-privacybrowser-history/. Accessed January 9, 2018.

Sadeghi, Yassmin. 2003. "USA PATRIOT Act violates our civil liberties." https://yaledailynews.com/blog/2003/10/07/usapatriot-act-violates-our-civil-liberties/. Accessed October 24, 2017.

Schiller, Herbert I. 1999. "US as global overlord: Dumbing down, American-style." http://www.hartford-hwp.com/ archives/27c/501.html. Accessed October 24, 2017. 
Schneider, Jessica. 2017. "DOJ demands Facebook information from 'anti-administration activists'” http://edition.cnn. com/2017/09/28/politics/facebook-anti-administrationactivists/index.html. Accessed October 24, 2017.

Seipe Brooke. 2017. "Trump redecorates Oval Office with golddrapes." http://thehill.com/blogs/in-the-know/in-theknow/315424-trump-remodels-oval-office-with-all-goldeverything. Accessed October 24, 2017.

Shamsian, Jacob. 2017. "President Trump's huge new plan for the internet could change it forever - here's how it'll affect you." Business Insider.

Smith, David, Ben Jacobsin, and Spencer Ackerman. 2017. "Sally Yates fired by Trump after acting US attorney general defied travel ban." https://www.theguardian .com/us-news/2017/ jan/30/justice-department-trump-immigration-actingattorney-general-sally-yates. Accessed October 24, 2017.

Sportsnet. 2016. "Gotta See It: Bomb sniffing dog drops ceremonial puck." https://www.youtube.com/watch? $\mathrm{v}=\mathrm{q}_{-}$ O92AxdttU. Accessed October 26, 2017.

Toobin, Jeffery. 2016. "Gawker's Demise and the Trump-Era Threat to the First Amendment." https://www.newyorker. com/magazine/2016/12/19/gawkers-demise-and-the-trumpera-threat-to-the-first-amendment. Accessed October 2, 2017.

Trump, Donald. 2016. Tweet. "Nobody should be allowed to burn the American flag - if they do, there must be consequences - perhaps loss of citizenship or year in jail!" https://twitter. com/realdonaldtrump/status/803567993036754944?lang=en. Accessed October 24, 2017.
Trump, Donald. 2017. Speech. "Remarks by President Trump on the Administration's National Security Strategy," The White House. https://www.white house.gov/briefings-statements/ remarks-president-trump-administrations-national-securitystrategy/. Accessed January 10, 2018.

US General Tommy Franks, quoted in the San Francisco Chronicle, March 23, 2002, online at https://www. globalsecurity.org/org/news/2002/020323-attack01.htm.

Vagianos, Alanna. 2017. "Kellyanne Conway: Trump's sexism isn't harming women the media is." https://www.huffingtonpost. com/entry/kellyanne-conway-trumps-sexism-isnt-harmingwomen-the-media-is_us_5956577fe 4 b05c37bb7dcf39. Accessed October 2, 2017.

Werfel, Franz. 1944. Between Heaven and Earth. New York: F. Hubner \& Company Inc.

White, Daniel. 2016. "Donald Trump Tells Crowd to 'Knock the Crap Out Of' Hecklers.” http://time.com/4203094/donaldtrump-hecklers/. Accessed October 24, 2017.

Wright, David and Sunlen Miller. 2007. "Obama dropped flag pin in war statement." http://abcnews.go.com/Politics/ story?id=3690000. Accessed October 4, 2017.

Zeleny, Jeff. 2007. “Obama's lapels.” https://thecaucus.blogs. nytimes.com/2007/ 10/04/obamas-lapels/ Accessed October 4, 2017. 
